\title{
Measuring Classified Circulation According to Curriculum
}

\begin{abstract}
Circulation statistics can be precise reflections of library use according to the curriculum. The statistics can help the librarian decide how to allocate the budget to departments. Traditional counts, by department personnel or by broad Dewey or LC classes, are imprecise. An analogy between curriculum and circulation can be constructed by classifying courses in the college catalog (by DC or LC), rearranging the numbers thus generated by department, and then counting circulation within those groups. The analogy is thus a quantitative measure and a precise reflection of library use according to curriculum.
\end{abstract}

$\mathrm{C}$

comparative use of the library by academic departments? What relationship does use of the library bear to the curriculum? How does one measure use according to curriculum instead of by department personnel?

These questions, and their variations, have long concerned the librarian who wants to know which departments are the heavy library users, and which should have the greater number of dollars for books. Traditional use counts may not give the answers. For example, some libraries categorize their loans according to the teaching departments whence the borrower comes. If an individual borrows ten books, ten loans are credited to his department. Such counts may not accurately reflect use according to the curriculum. A faculty member or student does not always borrow books which are exclusively related to his department or major. When a physics major borrows a mathematics book, should the loan reflect use according to the

Mr. McGrath is Head Librarian, South Dakota School of Mines and Technology, Rapid City. physics department or according to the mathematics department? Under usual procedure, the loan would be counted for physics. Many such loans would suggest that the physics department borrows more books than the mathematics department. But if the loans are a result of a mathematics assignment, or instigated in some other way by the mathematics department, or even by a third department, we ought not to give the credit to the physics department. As a parameter to help determine which department should receive the larger fund allotment for books, number of loans to department personnel is interesting, but unreliable. A simple head count of department members and enrollees, without a circulation count, might measure the same thing and would be simpler.

Other libraries keep count of circulation by broad Dewey or LC classification. These libraries can show that each year so many books were borrowed in the 300 's, the 400 's, the 500 's, the B's, the P's, the Q's, etc. These figures do a fine job of showing how many books were circulated in these broad classifications. But, as with loans to department personnel, the figures may bear little re- 
lationship to the curriculum. The scope of DC or LC classes does not necessarily coincide with the scope of a department's curriculum. Even when the broad classifications are broken down into more detail-let us say, in the DC classification, by the tens instead of by the hundreds-this still does not give us a true picture of curriculum use. Not all courses offered by the geology department fall into 550 's, and not all books in the 550's may be of interest to the geology department. Furthermore, a course normally thought of as falling within the scope of one department may be offered by another. At South Dakota School of Mines and Technology, for example, Descriptive Geometry (DC class 515) is offered by the civil engineering department, rather than the mathematics department.

Nevertheless, we would still like to know how many books borrowed relate to the geology curriculum, the civil engineering curriculum, the mathematics curriculum, and so on. Rather than counting heads or volumes in meaningless broad categories, a precise analogy can be created between circulation and the curriculum. This can be done by classifying a department course much as we do a book: according either to DC or LC. We then arrange sequentially the classification numbers thus generated, but within the departments. The resulting numbers, perhaps several hundred, form an analogy; and the circulation pattern therefore can reflect use by department subject alignments rather than by members or enrollment. Any book borrowed within the analogy would thus be counted for that department.

In another paper, ${ }^{1}$ the author used this device to establish an analogy between academic departments and the number of books published annually in the United States. The mechanism is the

\footnotetext{
${ }^{1}$ William McGrath, "Determining and Allocating Book Funds for Current Domestic Buying," College and Research Libraries, XXVII (July 1967), 269-72.
}

same. By classifying the courses; by grouping the classification numbers, whenever possible, into spans to embrace a larger subject scope; and by rearranging these numbers according to department, we can arrive at a total number of books published or circulated which have a direct relevance to the department concerned. By using the same sequence of numbers for both purposes (or for any other purpose), correlations can be drawn between books published and books circulated; and, of course, comparisons can be drawn between one department and any other.

Table 1 shows a selected list of assigned DC classes. These numbers (based on the 16th edition) codify the departments only at SDSM\&T, and naturally would vary somewhat from college to college. Note how they lend themselves to short or long spans but are sometimes quite specific and isolated. The long spans help to cut down the list and usually account for most of the titles in a department. But sometimes the specific numbers have considerable influence on a department total, especially if many books fall into that class, as is the case with 510.78 .

The daily tabulations are fitted into their spans and can be totaled as needed. Ideally, all sources of circulation

TABLE 1

Departments and Their Inclusive DC (16th) Groups-Partial List

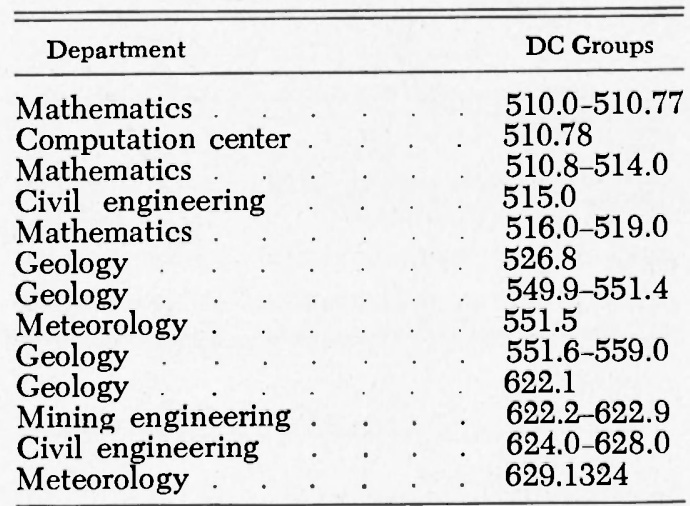


TABLE 2

Number of Circulated Books Relevant to Each Department ${ }^{*}$

\begin{tabular}{|c|c|c|c|c|}
\hline Department & No. of Books & $\begin{array}{l}\text { Per cent } \\
\text { of Total }\end{array}$ & Enrollment & $\begin{array}{l}\text { Circulation/ } \\
\text { Enrollment Ratio }\end{array}$ \\
\hline Biology & 142 & 2.19 & - & - \\
\hline Chemical engineering & 165 & 2.55 & 82 & 2.1 \\
\hline Chemistry & 363 & 5.60 & 42 & 8.6 \\
\hline Civil engineering & 543 & 8.38 & 108 & 5.0 \\
\hline Computation center & 142 & 2.19 & - & - \\
\hline Electrical engineering & 450 & 6.96 & 146 & 3.1 \\
\hline Geology & 600 & 9.26 & 36 & 16.7 \\
\hline Social science and humanities & 2180 & 33.65 & (Total) & 3.1 \\
\hline Mathematics & 560 & 8.64 & 34 & 16.5 \\
\hline Mechanical Engineering & 149 & 2.30 & 158 & .9 \\
\hline Metallurgy . & 421 & 6.50 & 37 & 11.4 \\
\hline Mining & 82 & 1.27 & 33 & 2.5 \\
\hline Paleontology (museum) & 24 & .37 & 4 & 6.0 \\
\hline Physical education & 53 & .82 & - & - \\
\hline Physics & 604 & 9.32 & 26 & 23.2 \\
\hline TOTAL & 6478 & 100.0 & 706 & 9.2 \\
\hline
\end{tabular}

- Because some categories have been left out, the figures cited in this paper do not necessarily represent the complete and true picture of SDSM\&T circulation.

should be tapped: department libraries, reserve, and other special collections. Unclassified periodicals cannot contribute to the statistics. Since periodicals are a special problem anyway, we are here dealing only with monographs.

Table 2 shows a typical set of figures for the number of circulated books relevant to each department. The loans, as distributed among the departments, reflect curriculum use of the library. Notice that the figure for social sciences and humanities (one department at South Dakota School of Mines and Technology) is much larger than any of the others. This is not surprising, even though a major is not offered in that department. Almost everyone, however, is interested in its books. A professor of mining engineering may as likely borrow Uses of the Past as Geochemical Methods of Prospecting. Furthermore, all students are required to read in the humanities. Such interest lends assurance to the feeling that humanities must not be neglected in a heavily weighted technical and scientific curriculum.

Physics and mathematics, two departments which are not only self-contained, but whose curriculums contribute to other departments, have a relatively small number of majors. Yet, as many, if not more, books circulate in these departments as in the high enrollment departments. This results in a high circulation/ enrollment ratio for mathematics and physics and suggests that at least these two departments, like the humanities department, need continued heavy support. Of course, other departments with high ratios or high circulation also need heavy support.

A note of caution is in order. Unless each department shares in the subject analysis and in the compilation of DC numbers, the faculty will be skeptical of results. The librarian must, therefore, interpret and use the results with great care.

With dangers recognized and proper care taken, this and similar studies can have considerable value. For example, data, as tabulated above, collected over a given time span, now make possible direct comparisons between the number of books published and the number of books borrowed. Such a study is now underway at SDSM\&T. From such data 
and studies we will be able to say that the books falling within the scope of one department are used more than another, and that we should perhaps buy more books in that area than in another.

Other functions which might be analyzed by the device are the existing book collection (measurable from the shelflist); books published throughout the world (measurable, say, through the British National Bibliography); number of periodicals published in the United States and throughout the world (measurable from such compilations as New Serial Titles-Classed Subject Arrangement); journal articles in abstracting publications which have a detailed classified arrangement, such as some of the Commonwealth Agricultural Bureau journals. Any of these media, especially those involving books, might be compared to the collections in large universities by actually measuring shelflists. The University of Michigan Undergraduate Shelflist would be a convenient tool to analyze, since it is generally available.

Additional studies in any of these media would have considerable value; and multivariate analyses such as multiple regression, of any or all, may be especially revealing.

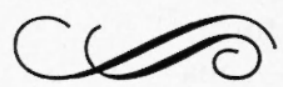

